\title{
Cerebellar-Degeneration-Related Antigen 1
}

National Cancer Institute

\section{Source}

National Cancer Institute. Cerebellar-Degeneration-Related Antigen 1. NCI Thesaurus. Code C25897.

Cerebellar degeneration-related antigen 1 (262 aa, $31 \mathrm{kDa}$ ) is encoded by the human CDR1 gene. This protein is involved in autoimmune diseases. 